reject supervision, resulting in deterioration of his mental state, he or she could be recalled to hospital. Such intervention would prevent further deterioration, allow treatment to be re-established, and promote the patient's return to the community.

Such a measure means accepting that compulsory powers are necessary to ensure that this circumscribed group of detained patients are encouraged to maintain their continued care in the community, rather than to be frequently detained in hospital or to become a casualty in the community..$^{13}$ Nevertheless, its introduction must be accompanied by improved organisation of clinical services in the community, including better deployment of community psychiatric nurses to care for patients with severe long term psychiatric illness and the provision of essential resources. ${ }^{16}$

Professor of Forensic Psychiatry,

ROBERT BLUGLASS

University of Birmingham,

Reaside Clinic,

Birmingham B34 9BE
1 Wallace M. Tortured world of the man in the lions' den. Daily Mail 1993;Jan 2.

2 Royal Commission on the law relating to mental illness and mental deficiency. Report. Cmnd 169 London: HMSO, 1957. (Chairman: Lord Percy of Newcastle.)

3 British Association of Social Workers. Mental health crisis services - a new philosophy. Birmingham: BASW, 1977

4 The Mental Health Act Commission. Fourth biennial repon 1989-1991. London: HMSO, 1991.

5 Brahams D. Treatment of unco-operative psychiatric patients in the community. Mental Health Act in need of reform. Lancet 1986-i:863-4.

6 Mental Health Act Commission. Compulsory treatment in the community: a discussion paper. London: Mental Health Act Commission, 1986.

7 Mental Health Act Commission. Compulsory treatment of the mentally disordered in the community: the field of choice. London: Mental Health Act Commission, 1988.

8 Royal College of Psychiatrists. Community treatment orders-a discussion document. London: Royal College of Psychiatrists, 1987.

9 British Medical Association. Annual report of Council 1988-9. London: BMA, 1989.

10 Dedman P. Compulsory treatment orders in Victoria, Australia. Psychiatric Bulletin 1990;14:462-4.

11 Sensky T, Hughes T, Hirsch S. Compulsory treatment in the communiry I. A controlled study of compulsory community treatment with extended leave under the Mental Health Act: Special compulsory community treatment with extended leave under the Mental Health Act: Special
characteristics of patients treated and impact of treatment. British Journal of Psychiatry characteristics of

12 Dunn J. Community treatment orders: do we need them? Yournal of Forensic Psychiatry 1991;2: 153-66.

13 MurphyE. Community treatment orders: do we need them? foumal of Forensic Psychiatry 1991;3:175-6. 14 Birley J. Community treatment orders: do we need them? Journal of Forensic Psychiatry 1991;3:176-8.

15 Sensky T, Hughes T, Hirsch S. Compulsory treatment in the community. II. A controlled study of patients whom psychiatrists would recommend for compulsory treatment in the community. Brf Psychiatry 1991;158:799-804.

16 Royal College of Psychiatrists. The mental healih of the nation. London: Royal College of Psychiatrists, 1992.

\title{
Respite care
}

\section{Should be made less difficult}

The importance of caring for carers is gradually being recognised. Anyone in any doubt of the need for providing such support will find a gruelling account of the problems faced by carers of elderly people in Margaret Forster's novel Have The Men Had Enough?'

There are not only humanitarian but also financial reasons for caring for carers. In Britain in 1986 an estimated 1.3 million carers kept dependants out of institutions, providing some $£ 7 \cdot 3$ billion worth of informal care. ${ }^{2}$ If only one in 10 of those people cared for at home had instead to be looked after in residential institutions the additional public cost would exceed $£ 1$ billion a year. Yet despite the value of their work, carers' needs are often overlooked, and they do not constitute a very active pressure group-perhaps because so much of their energy goes into caring. Could respite care help?

Respite care takes several forms: the challenge is to match these forms with needs. Admitting someone to hospital for respite care permits review of their problems-medical or otherwise-and drug regimens. Intensive courses of treatment, such as physiotherapy, can be arranged. Nevertheless, hospitals provide only a small proportion of respite careperhaps as little as $7 \%{ }^{3}$ This may be appropriate, not only because hospital beds are usually expensive but also because most people prefer to be looked after in the community. ${ }^{4}$

The new Community Care Act should prompt a fresh look at services for carers and those they look after. It states that "A key responsibility of statutory service providers should be to do all they can to assist and support carers." Authorities need to be well informed about who their local carers are and their particular needs and preferences. Do they want home based respite care or would they prefer a separate facility for respite care? What form or forms should this take? Particular attention needs to be given to the preferences of different racial, cultural, and religious groups. Do authorities know how many carers belonging to ethnic minorities they have in their district, how many require respite facilities, and how they fare compared with other carers? Checking such consumer needs should result in resources being used better. Obtaining this information locally is important but takes skill. ${ }^{\circ}$

The Community Care Act may have negative as well as positive consequences. These include possible reductions in care in the community owing to inadequate funding and the knock on effects on hospitals, which may face even greater difficulties in returning elderly people to the community than at present. Such pressure on places in both the acute and community sectors might in turn lead to a squeeze on the provision of respite care. Already evidence exists of underprovision of respite care: one recent study reported that a quarter of carers had not had a holiday for more than five years, ${ }^{7}$ and another found that $40 \%$ of carers could not take a break when they wanted. ${ }^{3}$

Any possibility of further reductions in respite care should be strenuously resisted. The humanitarian reasons for safeguarding this provision should be sufficient in themselves. Coupled with the financial implications if carers decided they could no longer shoulder this burden the case for supporting respite care becomes overwhelming.

Consultant Physician,

DAVID GRIFFITH

Department of Health Care for Older People,

Mayday University Hospital,

Thornton Heath,

Surrey CR7 7YE

1 Forster M. Have the men had enough? London: Penguin, 1990.

2 Family Policy Studies Centre. Caring costs: the social security implications. London: Family Policy Studies Centre, 1986

3 Whatmore K, Mira-Smith C. Eldercare in the 1990's. Vol 3. Survey tables. London: National Carers Survey Research Team, 1991.

4 Social Services Inspectorate, Department of Health. Carer suppon in the community. London: HMSO, 1991.

5 Secretaries of State for Health, Social Security, Wales, and Scotland. Caring for people: community care in the next decade and beyond - policy guidance. London: HMSO, 1989.

6 Robinson J, Yee L. Focus on carers. A practical guide to planning and delivering community care services. London: King's Fund Centre, 1991.

7 Jones DA, Peters TJ. Caring for elderly dependants: effects on the carers' quality of life. Age Ageing 992:21:421-8.

\section{Correction}

\section{The patient's charter and the triage nurse}

An editorial error resulted in the wrong reference being given at the end of the first sentence of the second paragraph of this editorial by Tom Keighley and Jan Maycock (28 November 1992, p 1310). The correct reference should have been reference 3 . 